\title{
Brazilian sardine (Sardinella brasiliensis) spawning in the southeast Brazilian Bight over the period 1976-1993
}

\author{
Yasunobu Matsuura \\ Instituto Oceanográfico da Universidade de São Paulo \\ (Caixa Postal 66149, 05315-970 São Paulo, SP,Brasil)
}

- Abstract: Based on sampling over the period 1976-1993 in the southeast Brazilian Bight, the distribution of spawning of the Brazilian sardine (Sardinella brasiliensis) is described in relation to environmental conditions. The area of intense spawning occurs in the southern part of the bight where coastal upwelling was less frequent. Spawning intensity showed high interannual variation and the egg abundance in the survey area ranged from 99 billion eggs in the January 1988 cruise to 4669 billion eggs in the January 1981 cruise. Peak spawning takes place one hour after midnight and eggs hatch out within 19 hours with a water temperature of $24^{\circ} \mathrm{C}$.

- Resumo: Baseado nos dados coletados durante nove cruzeiros oceanográficos realizados na região sudeste, as áreas de desova da sardinha-verdadeira (Sardinella brasiliensis) foram apresentadas e discutidas em relação às condições oceanográficas. As áreas de desova intensiva foram localizadas na parte sul da área de investigação, onde a ressurgência costeira foi menos freqüente. A intensidade de desova demonstrou uma variação anual relativamente grande. A produção total de ovos da sardinhaverdadeira variou de 99 bilhões de ovos durante o cruzeiro de janeiro de 1988 para 4669 bilhões de ovos em janeiro de 1981. O pico de desova ocorre na camada de mistura de superficie uma hora após a meia noite e os ovos eclodem em 19 horas com a temperatura de água $24^{\circ} \mathrm{C}$.

- Descriptors: Brazilian sardine, Spawning area, Southeast Brazilian Bight.

- Descritores: Sardinha-verdadeira, Área de desova, Região sudeste.

\section{Introduction}

The Brazilian sardine (Sardinella brasiliensis) fishery was started in the late 1950s and total landings increased during the $1960 \mathrm{~s}$, attaining the maximum eatch of 228 thousand tons in 1973. Over the next 15 vears, the total landings stayed at the level of 90-140 thousand tons. Recently landings declined to 31 thousand tons in 1990 , but recovered to 85 thousand tons in 1994.

The sardine fishery takes place in the coastal region of the southeast Brazilian Bight between $22^{\circ} \mathrm{S}$ and $29^{\circ} \mathrm{S}$, by small purse seiners. The Brazilian sardine is an isolated stock within the bight. It spawns

Contr. no. 813 do Inst. oceanogrda Usp in the coastal area during the late-austral spring and summer, but peak spawning occurs during December and January. First maturity is attained at $160 \mathrm{~mm}$ TL, at about one year old (Saccardo \& RossiWongtschowski, 1991).

Sardine spawning investigations were started in 1969 and many survey cruises have been undertaken since then (Matsuura, 1971; 1979). In this paper I describe the results of nine survey cruises carried out during the period 1976-1993.

\section{Material and methods}

The ichthyoplankton samples were collected with $60 \mathrm{~cm}$ Bongo nets during nine survey cruises in the area between Cape Frio $\left(23^{\circ} \mathrm{S}\right)$ and Cape Santa Marta Grande $\left(29^{\circ} \mathrm{S}\right)$ (Fig. 1). The station interval of the 
survey cruise was 20 n.m. with the exception of two cruises (Jan./1980 and Jan./1981), when a 30 n.m. interval was used. Numbers of sardine eggs at non-zero stations (Fig. 2) are represented by the size of the black dots. To estimate the spawning area the area represented by a polygon around the station (Sette \& Ahlstrom, 1948) was used.
The plankton samples taken with the coarse mesh net $(0.505 \mathrm{~mm})$ were preserved in a $10 \%$ formalin solution. Temperature and salinity were measured using a reversing thermometer with Nansen bottle or by CTD cast.

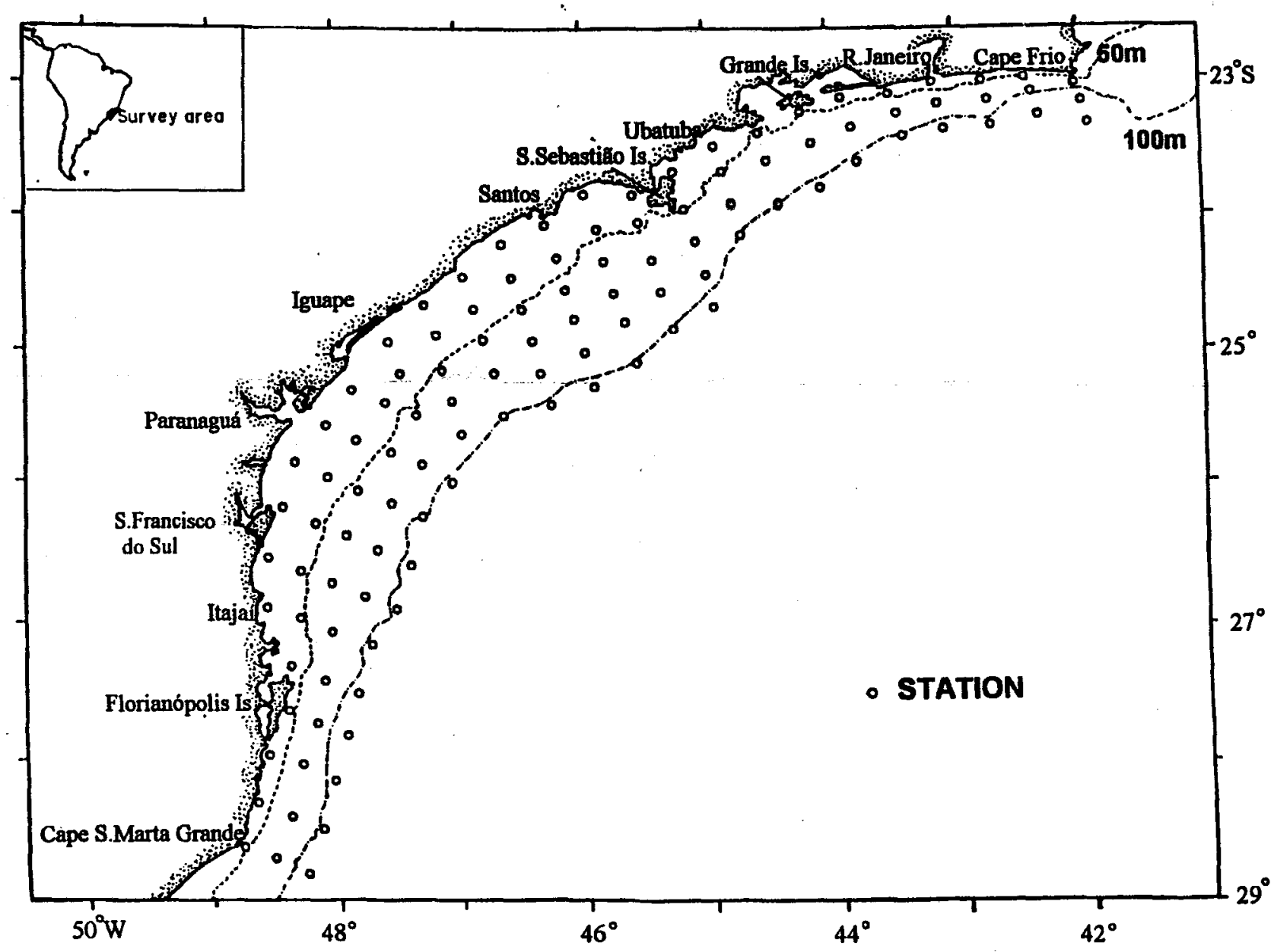

Fig. 1. Standard sampling stations during nine survey cruises in the southeast Brazilian Bight. 
Identification of the sardine eggs was based on the literature (Matsuura, 1971) and the embryonic stages of eggs were determined on the basis of Lo et al's criteria (1996). Total numbers of eggs taken were transformed into number per square meter of sea surface using the following expression (Tanaka, 1973):

$Y_{i}=\left(d_{i} \cdot x_{i}\right) / v_{i}$

where: $Y_{i}=$ number of standardized eggs per $1 \mathrm{~m}^{2}$ of sea surface at station $i ; x_{i}=$ number of eggs taken at station $\mathrm{i} ; \mathrm{v}_{\mathrm{i}}=$ volume of water filtered $\left(\mathrm{m}^{3}\right) ; \mathrm{d}_{\mathrm{i}}=$ maximum depth of haul (m).

The sardine eggs are distributed in the upper mixed layer (Matsuura et al., 1992), in which the water temperature is relatively homogeneous during the main spawning season, ranging from 22 to $26^{\circ} \mathrm{C}$ with an average of $24.6^{\circ} \mathrm{C}$. Average age of the embryonic stage from spawning was calculated using the equation given by Lo et al. (1996):

$Y_{i, t}=82.832 e^{-0.2103 t-0.1139 i+0.005 t i} i^{1.4024}$

Statistical estimates of standardized abundance of eggs were made using the delta-distribution (Pennington, 1983; 1996). Aitchison (1955) gave methods for estimating the mean and variance of a random variable that has a non-zero probability of being equal to zero and whose conditional distribution of non-zero values is lognormally distributed. This is our case as the average percentage of zero stations during nine cruises was $73.3 \%$ in the survey area and the non-zero values of positive stations were lognormally distributed.

\section{Results}

\section{Overall distribution of Sardine eggs in different years}

The distribution of sardine eggs in the period 1976-1980 is shown in Figure 2 (a,b,c,d). In general, there is a similarity between the distribution patterns of the eggs and the horizontal distribution of water temperature in different years. We can identify three spawning areas: State of Rio de Janeiro coast, off Santos-Iguape, and between Paranaguá and Itajaí. The highest egg abundance was found in the southern spawning area which extended from the coast to the
$100 \mathrm{~m}$ isobath line in most cases. Along the Rio de Janeiro coast, sardine eggs were found at coastal stations. The distribution pattern in the January 1981 cruise was similar to those of the previous four cruises, but the highest density of eggs (13,608 eggs $\mathrm{m}^{-2}$ ) was found at a station south of Santos (Fig. 2e).

The distribution pattern and egg density of the January 1988 cruise differed from those of all other cruises. Only nine of 78 sampling stations were positive for sardine eggs and the average egg density was the lowest $\left(1.1\right.$ eggs $\left.\mathrm{m}^{-2}\right)$ (Table 1). No coastal upwelling was observed at Cape Frio region, but was found around the Florianópolis Island. The spawning area was of only $9,290 \mathrm{~km}^{2}$ and all positive stations were close to the coast (Fig. 2f).

The last three cruises show a similar egg distribution pattern with three spawning areas: Ubatuba-Santos, Iguape-Paranaguá, and São Francisco do Sul-Florianópolis Island (Fig. 2 g,h,i). The January 1993 cruise showed a higher egg density than the other two cruises and also had a larger spawning area $\left(34,430 \mathrm{~km}^{2}\right)$. Along the Rio de Janeiro coast only minor percentages of sardine eggs were found nearshore on the three cruises.

Average temperature at $10 \mathrm{~m}$ depth for all positive stations was $24.3^{\circ} \mathrm{C}$ and the temperature of most of the stations fell within $21.3-27.3^{\circ} \mathrm{C}$ (Fig. 3). At some stations the thermocline was shallow, thus the temperature at $10 \mathrm{~m}$ depth showed low values which are related to the presence of South Atlantic Central Water at the surface. Average salinity was 35.2 psu, ranging from 33.2 to 37.1 psu.

\section{Peak spawning time and embryonic developmental stages}

Time of spawning can be deduced from the presence of early stage eggs in plankton samples. A comparison between sampling time and the developmental stages of eggs is shown in Figure 4. Most stage II eggs were found around 23:00-07:00 hours with an average time of 02:42. From the equation of Lo et al. (1996), the expected age of the stage II egg is about 1.42 hours after spawning at $24^{\circ} \mathrm{C}$. Therefore, the peak spawning should take place at around 01:18. The average time to hatchout at water temperature $24{ }^{\circ} \mathrm{C}$ will be about 18 hours 40 minutes. This means that the eggs spawned at one hour after midnight will hatch out at about 20:00 hours. 

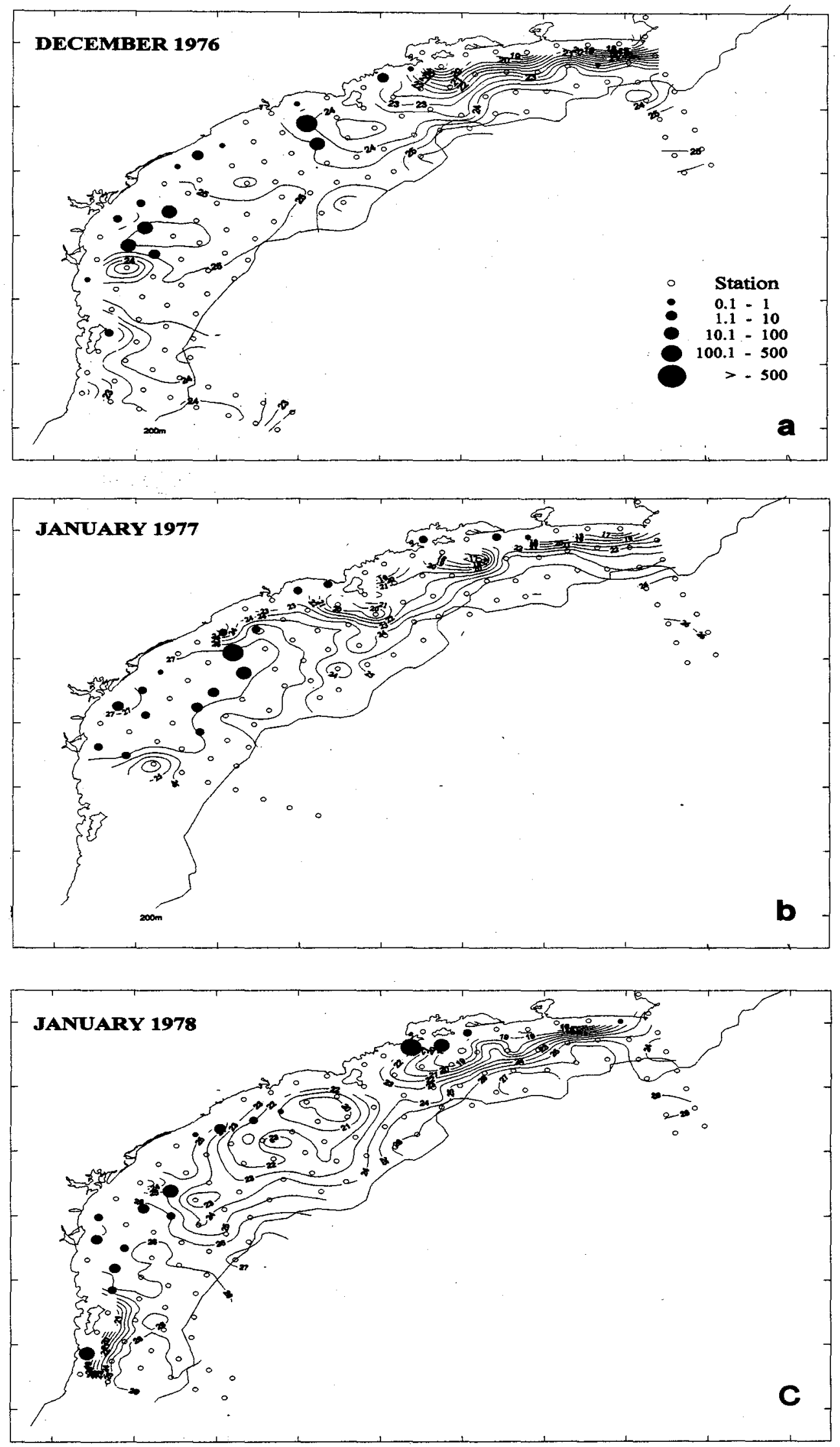

Fig. 2. Spawning areas of the Brazilian sardine. Number of sardine eggs per square meter of sea surface is presented by black dot. Horizontal distribution of water temperature at $10 \mathrm{~m}$ depth is shown by isoline with number in ${ }^{\circ} \mathrm{C}$. a) December 1976 , b) January 1977 , c) January 1978. 

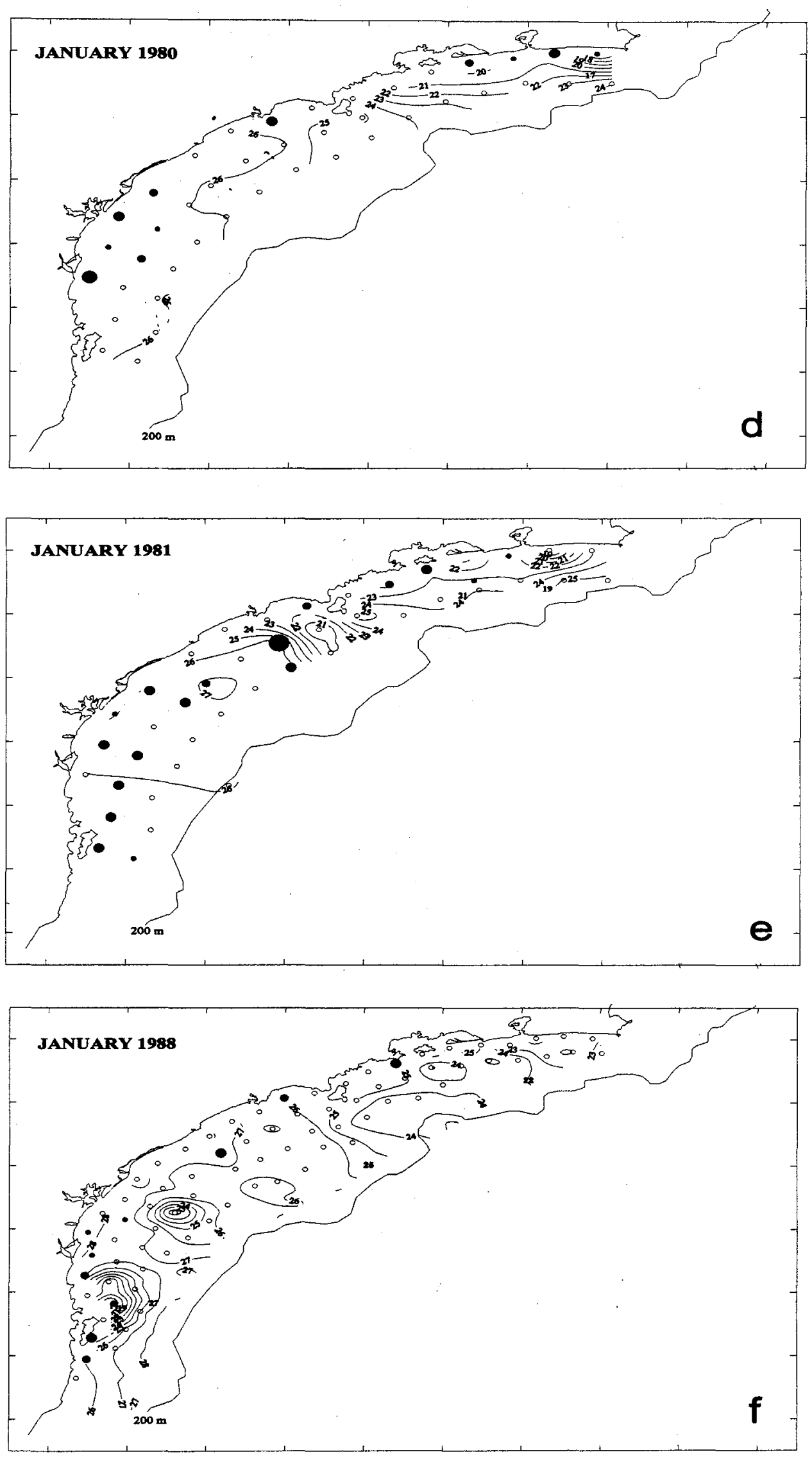

Fig. 2 (cont.). Spawning areas of the Brazilian sardine. d) January 1980, e) January 1981, f) January 1988. 

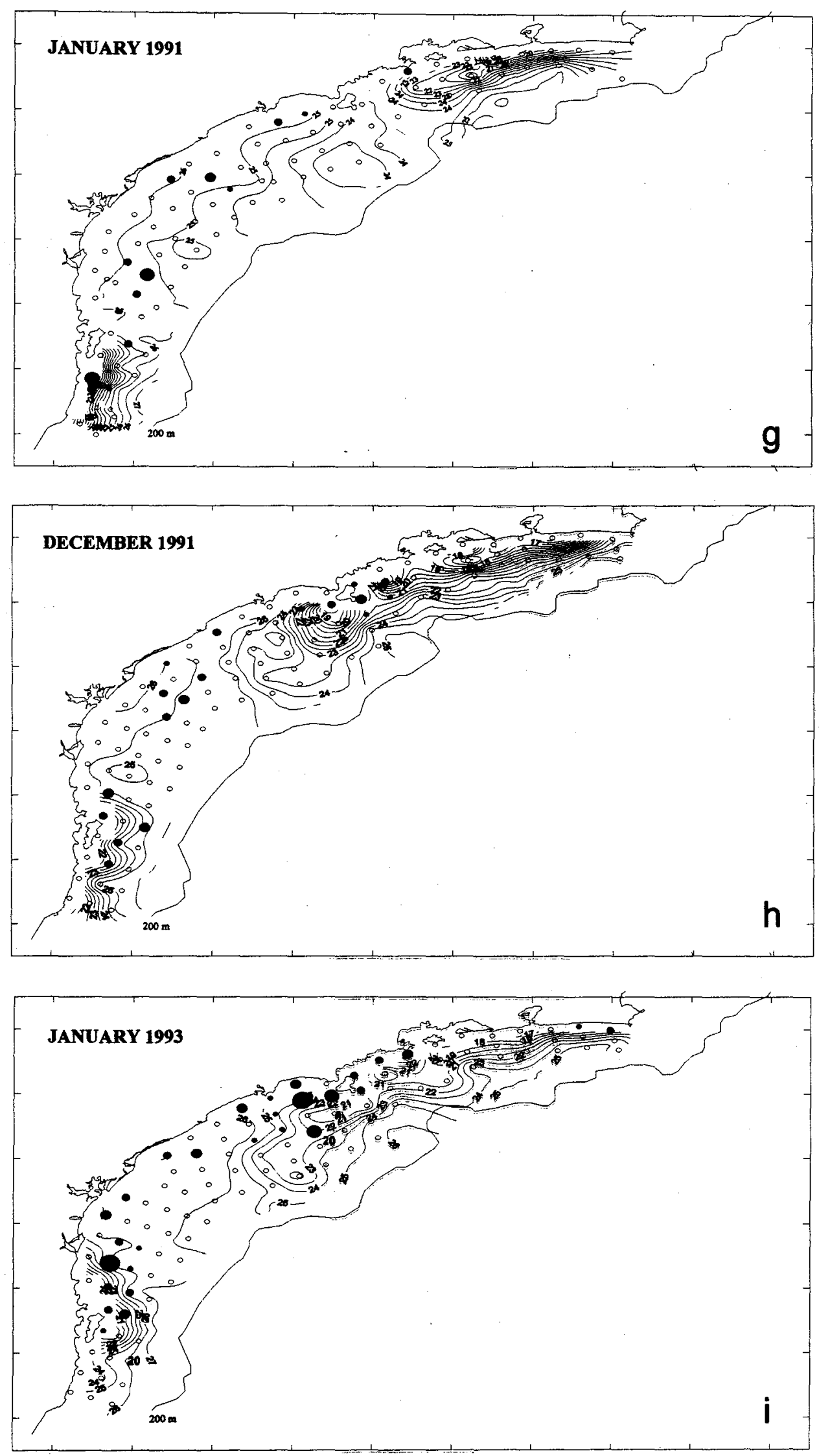

Fig. 2 (cont.). Spawning areas of the Brazilian sardine. g) January 1991, h) December 1991, i) January 1993. 
Table 1. Estimate of sardine egg numbers during nine survey cruises in the southeast Brazilian Bight.

\begin{tabular}{|c|c|c|c|c|c|c|c|c|}
\hline Cruise & No. Stations & $\begin{array}{c}\text { Number of } \\
\text { Positive } \\
\text { station }\end{array}$ & $\begin{array}{c}\text { Percentage of } \\
\text { Positive } \\
\text { stations }(\%)\end{array}$ & $\begin{array}{l}\text { Mean egg no. } \\
\text { (per square } \mathrm{m} \text { ) }\end{array}$ & Variance & $\begin{array}{l}\text { Spawning area } \\
\text { (in square } \mathrm{km} \text { ) }\end{array}$ & $\begin{array}{c}\text { Total no. } \\
\text { of egg } \\
\text { (in billion) }\end{array}$ & $\begin{array}{l}\text { St. error of } \\
\text { mean no. } \\
\text { of eggs }\end{array}$ \\
\hline December 1976 & 82 & 17 & 20.73 & 33.30 & 610.47 & 23213 & 3039.50 & 24.71 \\
\hline January 1977 & 69 & 18 & 26.09 & 7.63 & 17.23 & 25640 & 696.30 & 4.15 \\
\hline January 1978 & 82 & 17 & 20.73 & 27.24 & 27.24 & 20730 & 2486.20 & 5.22 \\
\hline Jamuary 1981 & 42 & 17 & 40.48 & 51.16 & 1300.99 & 42570 & 4669.80 & 36.07 \\
\hline January 1988 & 78 & 9 & 11.54 & 1.09 & 0.45 & 9290 & 99.00 & 0.67 \\
\hline January 1991 & 88 & 13 & 14.77 & 2.99 & 4.11 & 19730 & 273.10 & 2.03 \\
\hline December 1991 & 110 & 19 & 17.27 & 1.27 & 0.31 & 21250 & 115.70 & 0.56 \\
\hline January 1993 & 110 & 29 & 26.36 & 15.01 & 85.25 & 34430 & 1369.60 & 9.23 \\
\hline
\end{tabular}

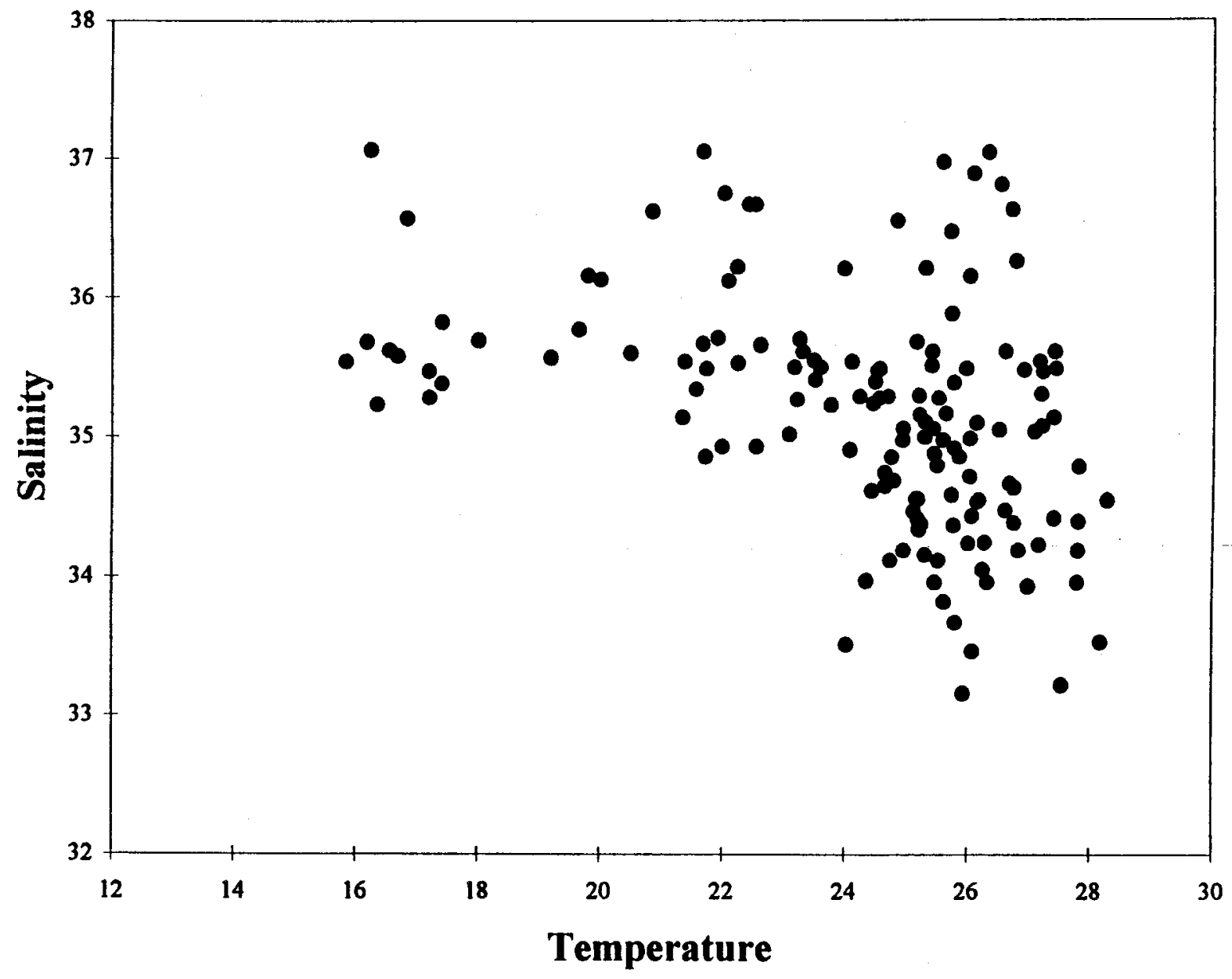

Fig. 3. Temperature and salinity at $10 \mathrm{~m}$ depth of positive stations of the Brazilian sardine eggs from nine survey cruises. 


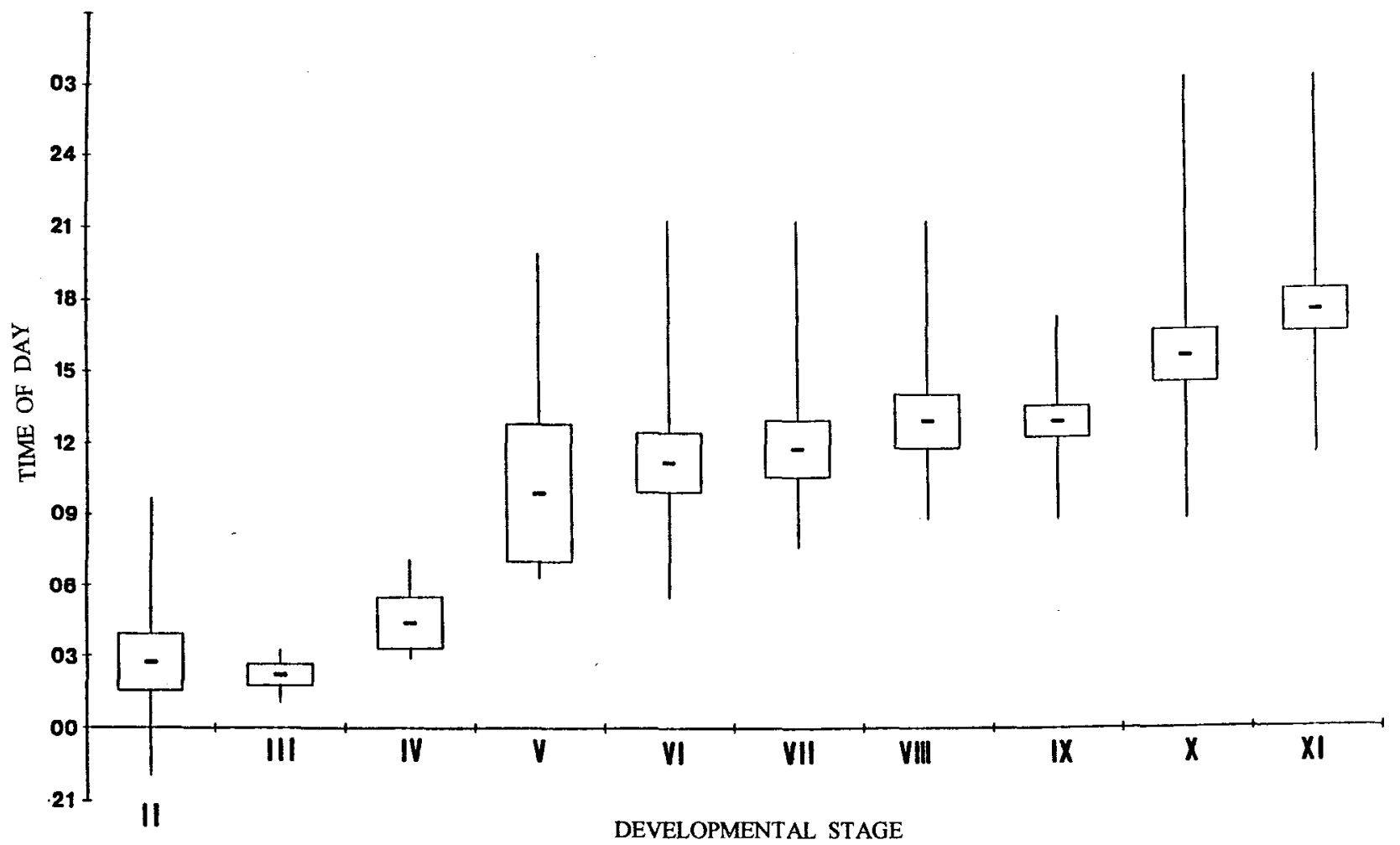

Fig. 4. Embryonic developmental stage in relation to sampling time. The graph shows the mean sampling time, \pm standard errors and minimum/maximum values.

\section{Total abundance of sardine eggs spawned in different years}

Within the southeast Brazilian Bight, sardine spawning normally takes place in the area between the coast and the $100 \mathrm{~m}$ isobath, with the exception of the Rio de Janeiro coast where some sardine eggs were taken at stations seaward of the $100 \mathrm{~m}$ line. The standard survey area presented in Figure 1 has a total area of $91,278 \mathrm{~km}^{2}$. The total number of sampling stations in this area varied from 42 to 110 and the proportion of positive stations ranged from $11.5 \%$ to $40.4 \%$ (Table 1 ). The average density of sardine eggs ranged from 1.08 eggs m $\mathrm{m}^{-2}$ from $9,290 \mathrm{~km}^{2}$ of spawning area in January 1988 to $51.16 \mathrm{eggs} \mathrm{m}^{-2}$ from $42,570 \mathrm{~km}^{2}$ in January 1981 (Fig. 5). Total numbers of sardine eggs in different spawning seasons ranged from 99 billion eggs in January 1988 to 4669 billion eggs in January 1981. It is clear that sardine spawning was low during three spawning seasons, namely January 1988, January 1991 and December 1991. The number of sardine eggs spawned and the spawning area of the last survey cruise in January 1993 showed a recovery of spawning activity with a total egg abundance of 1369 billions.

\section{Discussion}

During the first five cruises, coastal upwelling was observed along the coast of Rio de Janeiro and the cold surface layer extended from Cape Frio to Grande Island, except for the January 1981 cruise, when upwelling was limited to Cape Frio (Fig. 2e). Most spawning took place in the southern area where the coastal upwelling was less frequent. During the last three cruises (1991-1993) the coastal upwelling was observed in two areas: off Cape FrioGrande Island and off Florianópolis Island-Cape Santa Marta Grande. During the austral summer the South Atlantic Central Water (SACW) intrudes into the coastal region along the bottom layer over the continental shelf. The presence of the SACW in the bottom layer of the coastal region seems to be important for the creation of the sardine spawning habitat, as it implies an input of the nutrient rich water mass in the euphotic zone. An oceanic front is formed at the sea bottom between the warm Coastal Water and the cool SACW and runs from Itajai to Ubatuba along the $50 \mathrm{~m}$ isobath line (Matsuura, 1996). 


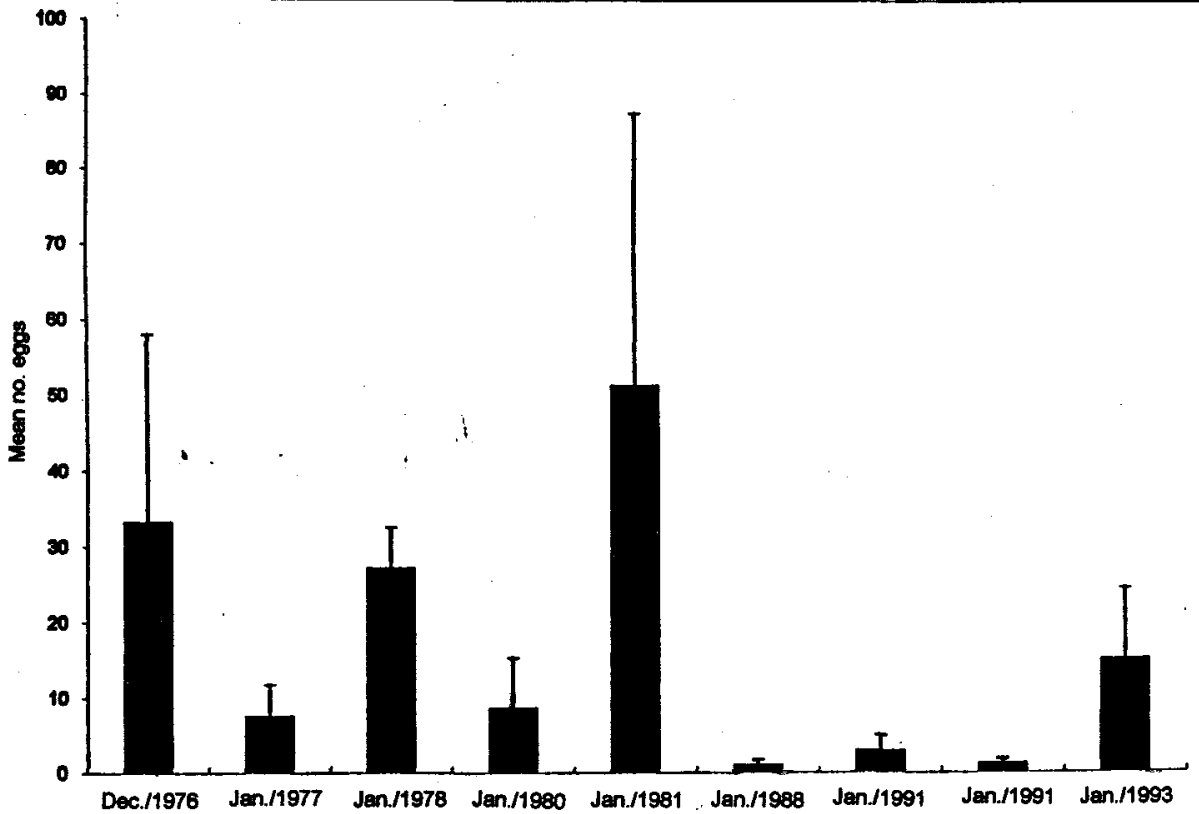

Fig. 5. Estimates of mean density of the sardine eggs during nine survey cruises. Bar shows mean egg density at each cruise with standard errors of means shown in T-line.

The spawning area showed some annual variation in its location, but the main southern spawning ground was consistently found between Paranaguá and Florianópolis Island on nine cruises. During the last two cruises (December 1991 and January 1993) a large spawning ground was formed around the São Sebastião Island, but this area was not used for spawning during the other seven cruises.

The sardine population in the bight was stable over the period 1974-1987, maintaining total annual landings of 90-140 thousand tons. Due to an oceanographic anomaly in the $1986 / 1987$ spawning season, a recruitment failure occurred in the 1987 year class, resulting in a drastic decline of the spawning stock biomass in subsequent years (Castello et al., 1991; Matsuura et al., 1992; Cergole, 1995). This population decline was confirmed in the present study by very low egg density on the January 1988 cruise and the poor spawning continued until the 1991/1992 spawning seasons.

The time of sardine spawning has been determined by the presence of early stage eggs taken at a certain time of day in the sea and normally occurring during the night (Ahlstrom, 1943; Cushing, 1960; Simpson \& Gonzalez, 1967; Simpson, 1971; Matsuura, 1983; Alheit et al., 1987). Nocturnal spawning of the clupeoids is a common behavior pattern and appears to be related to a survival strategy of pelagic fishes to protect the recently-spawned eggs from carnivorous predators in the surface layer. Only the SW Atlantic anchovy (Engraulis anchoita) on the southeast coast of Brazil spawns throughout all the day in the less illuminated bottom layer (Asano et al., 1991). On the other hand the spawning of demersal fish takes place in general at sunset (Colin et al., 1987; Colin, 1992 for groupers; Blaxter \& Holliday, 1963 for herring; Carter
\& Perrine, 1994; Cuellar et al., 1996 for snappers; Lobel, 1978 for angelfish).

The duration of each developmental stage at different temperatures has been measured experimentally for sardine (Sardinops spp.) eggs. At lower temperature the development of embryos at stages VII, VIII, and IX is delayed relative to other stages (Ito, 1958; Le Clus \& Malan, 1995). Consequently the developmental curve between egg stage and embryonic age at lower temperature is sigmoidal, but at higher temperatures the relationship is nearly linear. The embryonic developmental curve for Sardinella brasiliensis is almost linear in these observations, with $r=0.95$. Goodness of lit tests for regression (temperature-corrected age of each stage versus mean sampling time) showed that the curvilinearity of regression was rejected with $p=0.05$ $(\mathrm{F}=4.196$ withd.f. 1 and 8$)$.

Using Lo et al. 's equation (1996), the embryonic mortality rate was estimated based on the samples taken on four survey cruises (From Jan.88 to Jan.93). The mortality rate obtained from this calculation was 0.61 with $r=0.16$. An attempt was made to estimate the embryonic mortality rate for the other 5 cruises (From Dec.76 to Jan.81), using the temperaturecorrected age of embryos based on Nakai's equation (1962). The coefficient of the linear regression between mean age of each developmental stage versus $\mathrm{Ln}$ (mean sampling time) is -0.043 with $r=0.028$. These results indicate that when the Bongo nets were used, the large sampling variability makes the mortality estimate meaningless. The embryonic mortality rates for sardine and anchovy were normally estimated on the basis of the plankton samples collected with the CalVET net, which shows less sampling variability. The daily mortality rate of the northern anchovy (Engraulis 
mordax) eggs based on the CalVET samples ranged from 0.14 to 0.45 (Picquelle \& Hewitt, 1983; 1984). Asano et al. (1991) obtained the daily embryonic mortality rate of 0.32 for Engraulis anchoita in the same area for the Brazilian sardine and Lo et al. (1996) obtained 0.12 for Sardinops sagax in southern California.

Total egg production estimated for nine cruises showed relatively high inter-annual variation. Comparison of the spawning stock biomass estimated by VPA (Cergole, 1995) and daily egg production from eight cruises shows that there is a positive correlation among them with a coefficient of correlation, $r=0.81$. Therefore, we may conclude that the spawning intensity measured by egg abundance is representative of spawning stock density, exception made of the January 1981 cruise.

\section{Acknowledgements}

The author wishes to thank Dr. Alec D. MacCall of the Southwest Fisheries Science Center for the revision and critical reading of the manuscript. I also thank the captain W.C. Freitas and crew of the R/V "Prof. W Besnard" for their cooperation during survey cruises. The present investigation received the financial support of the CIRM, FAPESP and CNPq. The author received a research fellowship of the $\mathrm{CNPq}$ (process no. 301675/82) during investigation. This is a product of the SCOR Working Group 98. Two anonymous reviewers are thanked for their useful comments and suggestions.

\section{Reference}

Ahlstrom, E. H. 1943. Studies on the Pacific pilchard or sardine (Sardinops caerulea). 4. Influence of temperature on the rate of development of pilchard eggs in nature. Spec. scient. Rep., U.S. Fish Wildl. Serv., 23:1-26.

Aitchison, J. 1955. On the distribution of a positive random variable having a discrete probability mass at the origin. J. Am. statist. Ass., 50:901-908.

Alheit, J.; Wahl, E. \& Cihangir, B. 1987. Distribution, abundance, development rates, production and mortality of sprat eggs. ICES. Counc. Meet. $7 p$.

Asano, K.; Matsuura, Y. \& Katsuragawa, M. 1991. Daily egg production of the Brazilian anchovy, Engraulis anchoita. Bull. Fac. Bioresour., Mie Univ., 6:47-55.
Blaxter, J. H. S. \& Hollyday, F. G. T. 1963. The behaviour and physiology of herring and other clupeoids. Adv. mar. Biol., 1:261-393.

Carter, J. \& Perrine, D. 1994. A spawning aggregation of dog snapper, Lutjanus jocu (Pisces: Lutjanidae) in Belize, Central America. Bull. mar. Sci., 55(1):228-234.

Castello, J. P.; Habiaga, R. P.; Amaral, J. C. \& Lima Jr, I. D. 1991. Prospecção hidroacústica e avaliação da biomassa de sardinha e anchoita, na região sudeste do Brasil (outubro/novembro de 1988). Publção esp. Inst. oceanogr., S Paulo, (8):15-29.

Cergole, M. C. 1995. Stock assessment of the Brazilian sardine, Sardinella brasiliensis, of the southeastern coast of Brazil. Scientia Marina, 59(3-4):597-610.

Colin, P. L.; Shapiro, D. Y. \& Weiler, D. 1987. Aspects of the reproduction of two groupers, Epinephelus guttatus and E. striatus in the West Indies. Bull. mar. Sci., 40(2):220-230.

Colin, P. L. 1992. Reproduction of the Nassau grouper, Epinephelus striatus, (Pisces: Serranidae) and its relationship to environmental conditions. Envir. Biol. Fish., 34(4):357-377.

Cuellar, N.; Sedberry, G. R. \& Wyanski, D. M. 1996. Reproductive seasonality, maturation, fecundity, and spawning frequency of the vermilion snapper, Rhomboplites aurorubens, off the southeastern United States. Fish. Bull., 94(4):635-653.

Cushing, D. H. 1960. Fishing gear and fish behaviour. In: Rosa Jr., H. \& Murphy, G. eds Proceedings of the world scientific meeting on the Biology of sardines and related species. Koma, FAO. 3:13071326.

Ito, S. 1958. On the relation between water temperature and incubation time of sardine (Sardinops melanosticta). Ann. Rep. Japan Sea reg. Fish. Lab., 4:25-31.

Le Clus, F. \& Malan, P. E. 1995. Models of temperature-dependent rate of development of pilchard Sardinops sagax eggs, to be used in routine procedures for estimating daily egg production. S. Afr. J. mar. Sci., 16:1-8.

Lo, N. C. H.; Ruiz, Y. A. G.; Cervantes, M. J.; Moser, H. G. \& Lynn, R. J. 1996. Egg production and spawning biomass of Pacific sardine (Sardinops sagax) in 1994, determined by the daily egg production method. CalCOFI Rept., 37:160-174. 
Lobel, P. S. 1978. Diel, lunar, and seasonal periodicity in the reproductive behavior of the Pomacanthid fish, Centropyge potteri, and some other reef fishes in Hawaii. Pacif. Sci., 32(2):193-207.

Matsuura, Y. 1971. A study of the life history of Brazilian sardine, Sardinella aurita. I. Distribution and abundance of sardine eggs in the region of Itha Grande, Rio de Janeiro. Bolm Inst. oceanogr., S Paulo, 20(1):33-60.

Matsuura, Y. 1979. Distribution and abundance of eggs and larvae of the Brazilian sardine, Sardinella brasiliensis, during 1974-75 and 1975-76 seasons. Bull. japan. Soc. Fish. Oceanogr., 34:1-12.

Matsuura, Y. 1983. Estudo comparativo das fases iniciais do ciclo de vida da sardinha-verdadeira, Sardinella brasiliensis e da sardinha-cascuda, Harengula jaguana, (Pisces: Clupeidae) e nota sobre a dinâmica da população da sardinha-verdadeira na região sudeste do Brasil. Tese de livre-docência. Universidade de São Paulo. Instituto Oceanográfico. 150p.

Matsuura, Y. 1996. A probable cause of recruitment failure of the Brazilian sardine Sardinella aurita population during the 1974/1975 spawning season. S. Afr. J. mar. Sci., 17:29-35.

Matsuura, Y.; Spach, H. L. \& Katsuragawa, M. 1992. Comparison of spawning patterns of the Brazilian sardine (Sardinella brasiliensis) and anchoita (Engraulis anchoita) in Ubatuba region, southern Brazil during 1985 through 1988. Bolm Inst. oceanogr., S Paulo, 40(1/2):101-115.

Nakai, Z. 1962. Studies of influences of environmental factors upon fertilization and development of the Japanese sardine eggs with some reference to the number of their ova. Bull. Tokai reg. Fish. Res. Lab., 9:109-150.

Pennington, M. 1983. Efficient estimators of abundance, for fish and plankton surveys. Biometrics, 39:281-286.
Pennington, M. 1996. Estimating the mean and variance from highly skewed marine data. Fish. Bull., 94(3):498-505.

Picquelle, S. J. \& Hewitt, R. 1983. The northern anchovy spawning biomass for the 1982-1983 California fishing season. CalCOFI Rept., 24:1628.

Picquelle, S. J. \& Hewitt, R. 1984. Estimates of the spawning biomass of the northern anchovy for the 1983-1984 California fishing season. CalCOFI Rept., 25:16-27.

Saccardo, S. A. \& Rossi-Wongtschowski, C. L. D. B. 1991. Biologia e avaliação do estoque da sardinha Sardinella brasiliensis: uma compilação. Atlântica, Rio Grande, 13(1):29-43.

Sette, O. E. \& Ahlstrom, E. H. 1948. Estimations of abundance of the eggs of the Pacific pilchard (Sardinops caerulea) off southern California during 1940 and 1941. J. mar. Res., 7(3):511-542.

Simpson, A. C. 1971. Diel spawning behaviour in populations of plaice, dab, sprat and pilchard. J. du Cons., 34;58-65.

Simpson, J. G, \& Gonzalez, G. 1967. Some aspects of the early life history and environment of the sardine, Sardinella anchovia, in eastern Venezuela. Ser. Recur. Explot, Pesq., 1(2):38-83.

Tanaka, S. 1973. Stock assessment by means of ichthyoplankton surveys. FAO Fish. tech. Pap., 122:33-51.

(Manuscript received 27 October 1997; revised 12 February 1998; accepted 08 April 1998) 